УДК 669.0:004.9

\title{
Computer Modeling of the Soderberg's Cell with the Use of Anode's Cooling Fins
}

\author{
Matvey V. Golubeva, \\ Yaroslav A. Tretiyakov ${ }^{\mathrm{a}}$, Aleksandr I. Bezrukikh ${ }^{*}$, \\ Aleksey A. Iliin a and Andrey B. Klyuchantseva

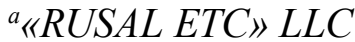 \\ 37/1 Pogranichnikov, Krasnoyarsk, 660111, Russia \\ ${ }^{b}$ Siberian Federal University \\ 79 Svobodny Krasnoyarsk, 660041, Russia
}

Received 19.04.2016, received in revised form 28.06.2016, accepted 15.08.2016

Soderberg's cell there is the problem of overheating of the anode paste and increasing mass of the bakedome in the center of the anode and low temperatures (down to freezing in winter) in the periphery. Increasing the height of the bakedome in the central part affects the formation of the anode and consequently on the physical and mechanical properties of the anode, increasing the porosity, electrical resistance and reducing mechanical strength [1]. This paper presents the simulation results of cell's temperature fields (S8-BM) with anode's cooling fins.

Keywords: Soderberg's cell, anode, cooling fins, computer modeling, cell's temperature fields.

Citation: Golubev M.V., Tretiyakov Y.A., Bezrukikh A.I., Iliin A.A., Klyuchantsev A.B. Computer modeling of the soderberg's cell with the use of anode's cooling fins, J. Sib. Fed. Univ. Eng. technol., 2016, 9(6), 880-886. DOI: 10.17516/1999-494X-20169-6-880-886.

(C) Siberian Federal University. All rights reserved

* Corresponding author E-mail address: abezrukikh@sfu-kras.ru 


\title{
Компьютерное моделирование работы электролизера \\ с самообжигающимся анодом \\ с применением ребер охлаждения в теле анода
}

\author{
М.В. Голубев ${ }^{\text {, }, ~ Я . А . ~ Т р е т ь я к о в ~}{ }^{\mathrm{a}}$, \\ А.И. Безруких ${ }^{\sigma}$, А.А. Ильин ${ }^{\text {a }, ~ А . Б . ~ К л ю ч а н ц е в ~}{ }^{\text {a }}$ \\ ${ }^{a}$ ООО «РУСАЛ ИТЦ» \\ Россия, 660111, Красноярск, Пограничников, 37/1 \\ ${ }^{6}$ Сибирский федеральный университет \\ Россия, 660041, Красноярск, Свободный, 79
}

\begin{abstract}
На электролизерах с анодом Содерберга существует проблема перегрева анодной массы и увеличения конуса спекания в центре анода и низких температур (вплоть до смерзания в зимнее время) на периферии. Увеличение высоты конуса спекания в центральной части отрицательно влияет на формирование анода и, как следствие, на физико-механические свойства анода, увеличивая пористость, удельное электросопротивление и снижая механическую прочность. В данной статье представлены результаты моделирования температурных полей электролизеров С8-БМ с ребрами охлаждения в теле анода.
\end{abstract}

Ключевые слова: электролизер Содерберга, анод, ребра охлаждения, компьютерное моделирование, температурные поля электролизера.

\section{Введение}

На электролизерах с анодом Содерберга существует проблема перегрева анодной массы и увеличения конуса спекания в центре анода и низких температур (вплоть до смерзания в зимнее время) на периферии. Увеличение высоты конуса спекания в центральной части отрицательно влияет на формирование анода и, как следствие, на физико-механические свойства анода, увеличивая пористость, удельное электросопротивление и снижая механическую прочность [1]. В данной статье представлены результаты моделирования температурных полей электролизеров С8-БМ с ребрами охлаждения в теле анода.

Опыт установки охлаждающих ребер на поверхность анода Содерберга [2, 3] с погружением в зону расплавленной коксопековой композиции (КПК) позволяет сделать вывод о возможности частичного управления высотой конуса спекания [4, 5].

Задачей моделирования является оценка влияния различных конструкций ребер охлаждения на температурное поле анода и высоту конуса спекания.

Расчеты были выполнены с использованием программного пакета ANSYS, который с помощью метода конечных элементов позволяет решать стационарные и нестационарные задачи теплопередачи и теплообмена. Данный программный комплекс - довольно известная САЕсистема, применяемая на ведущих предприятиях промышленности РФ и мира.

\section{Методика моделирования}

Для оценки различной конструкции ребер охлаждения вначале была создана исходная модель электролизера С8-БМ, представленная на рис. 1. 
После расчетов данной модели была проведена идентификация при помощи сопоставления результатов измерений температурных параметров действующей ванны и результатов расчета модели. В модель были введены поправочные коэффициенты; результаты расчетов температурного поля идентифицированной модели отражены на рис. 2.

Далее были рассмотрены предложенные варианты систем охлаждения анода в виде алюминиевых ребер различной конфигурации, установленных на поверхность анода с погружением в зону расплавленной КПК на 300 мм. На рис. 3 представлены геометрические модели с ребрами охлаждения.

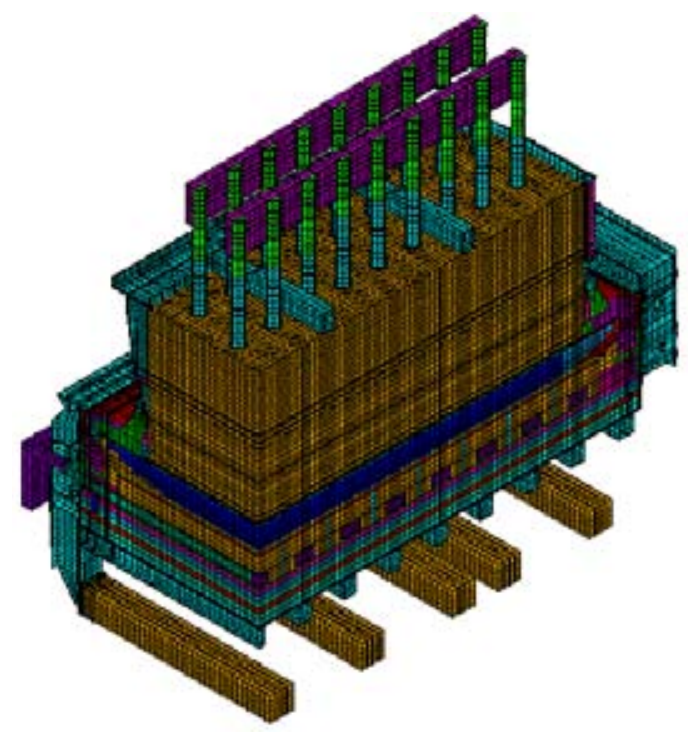

Рис. 1. Модель электролизера С8-БМ с конечно-элементной сеткой

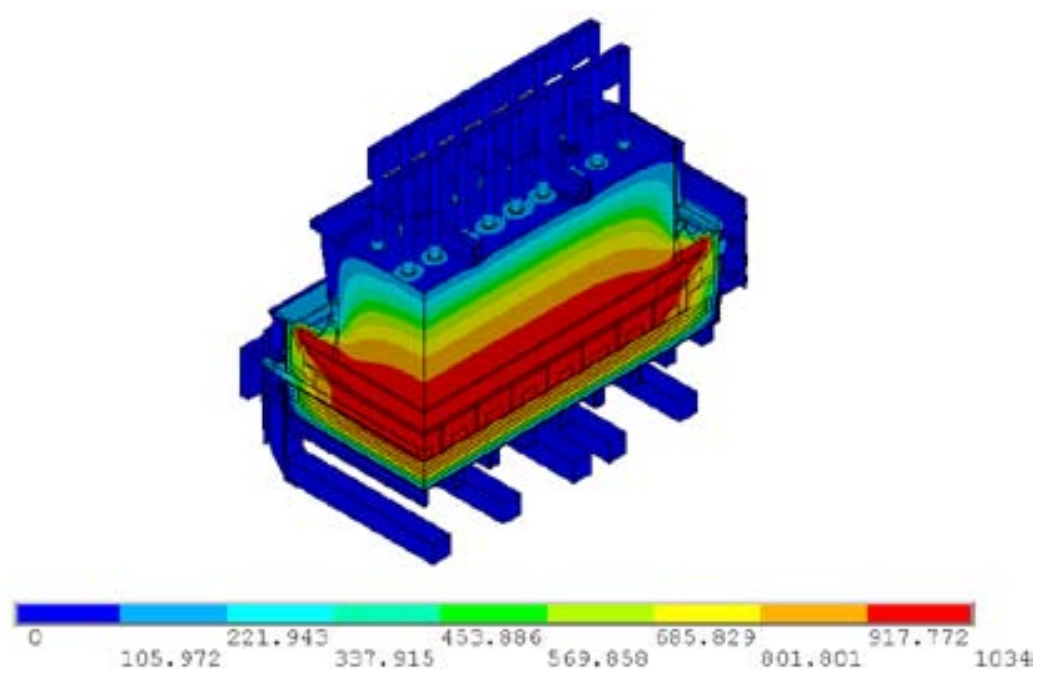

Рис. 2. Температурное поле электролизера С8-БМ (исходная модель, без ребер) после идентификации модели 

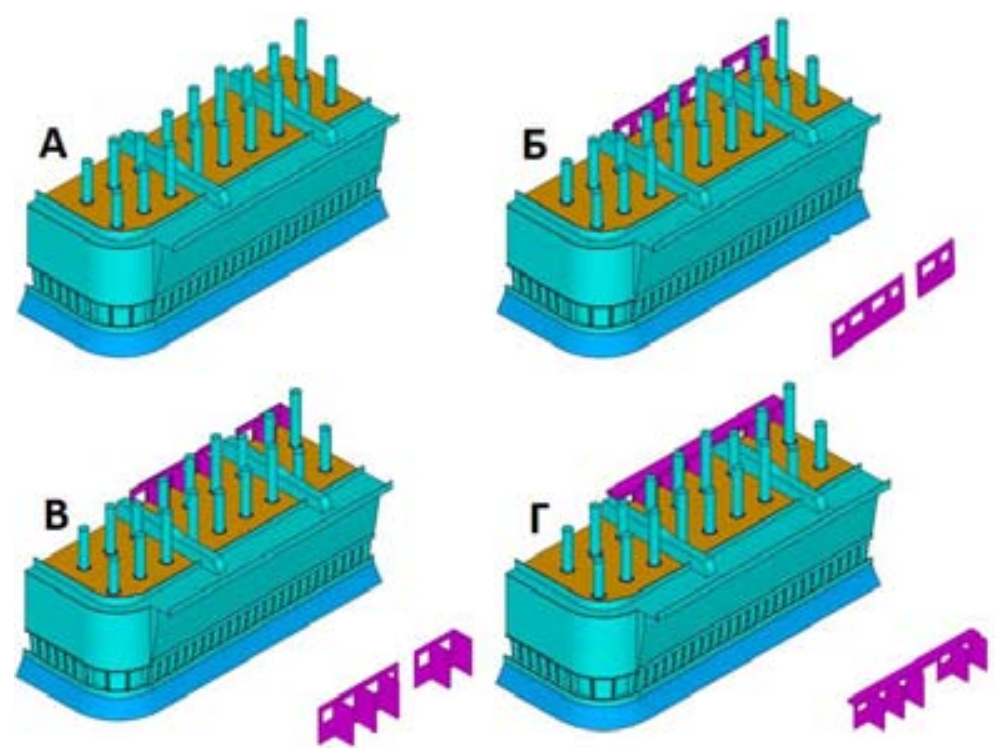

Рис. 3. Геометрические модели анода электролизера С8-БМ: а - исходный вариант без ребер охлаждения; б - с продольным ребром; в - продольное ребро с поперечными ребрами; г - продольное ребро с поперечными ребрами и алюминиевым трапиком
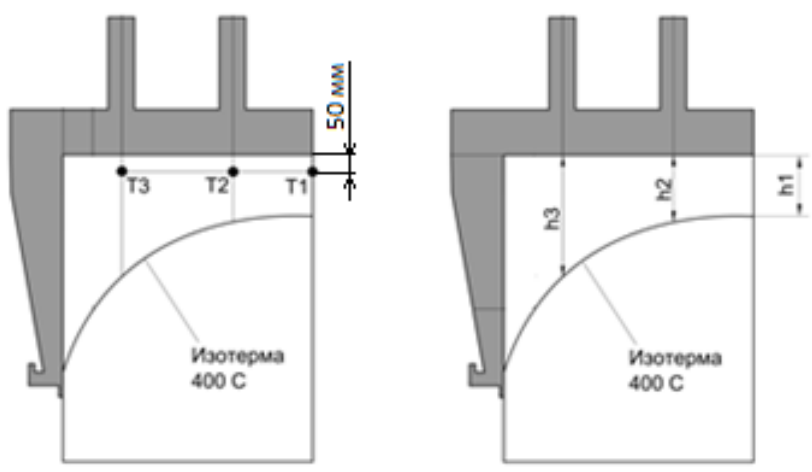

Рис. 4. Схема измерения параметров температуры (T) в плоскости симметрии анода и высоты конуса спекания (h)

Для оценки результатов моделирования были использованы следующие параметры: температура анодной массы на глубине 50 мм от поверхности (точка измерения при технологических замерах), высота конуса спекания по центру анода от края поверхности анодного массива до нижней границы изотермической кривой, равной $400{ }^{\circ} \mathrm{C}$. На рис. 4 изображены схемы оценки параметров результатов моделирования.

\section{Результаты моделирования}

Для оценки изменения конуса спекания на рис. 5 отражены результаты расчета теплового поля анода для разных вариантов в диапазоне температур $0-400{ }^{\circ} \mathrm{C}$. Серым цветом выделена область выше $400{ }^{\circ} \mathrm{C}$. 
По результатам расчетов видно, что в случае установки ребер охлаждения в тело анода существенно меняется профиль конуса спекания. Происходит существенное снижение его высоты по центру анода и различное снижение по периферии в зависимости от конструкции ребер. Также наблюдается изменение профиля вдоль анода, при установке ребер профиль становится волнообразным.

Наибольшее снижение высоты конуса спекания и температуры по центру анода наблюдается для конструкции ребер по варианту Г. В данном случае КПК по центру (параметр h1, рис. 4) увеличивается на 155 мм до значения 495 мм, а температура по центру (точка T1, рис. 4) падает с 152 до $79^{\circ} \mathrm{C}$. Уровень КПК по периферии (параметр h3, рис. 4) увеличивается на 22 мм, а температура периферии (точка Т3, рис. 4) снижается на $5{ }^{\circ} \mathrm{C}$.

Серым цветом на рис. 5 обозначена область с температурой выше $400{ }^{\circ} \mathrm{C}$, повторяющая форму конуса спекания.

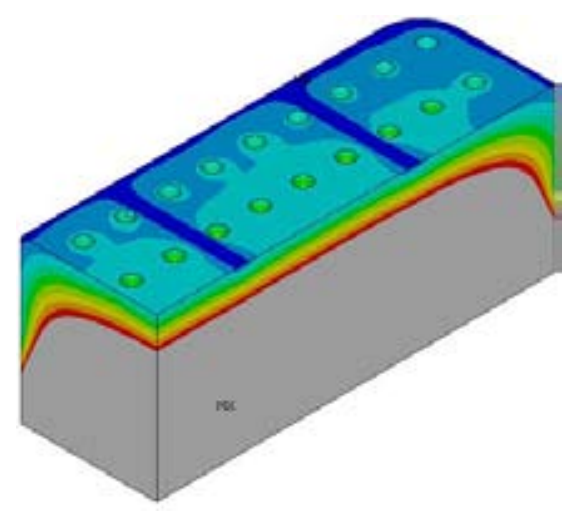

a

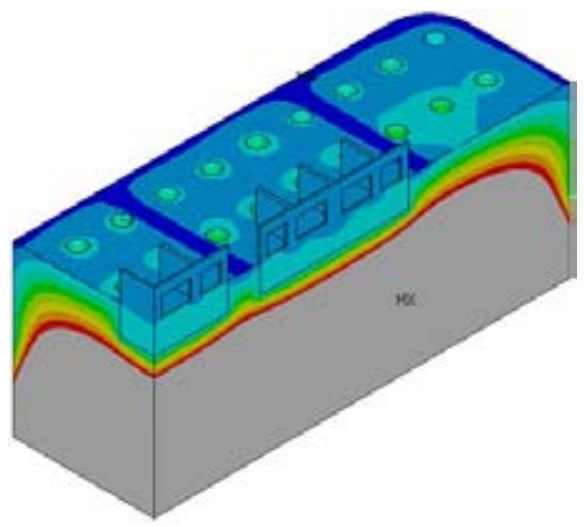

B

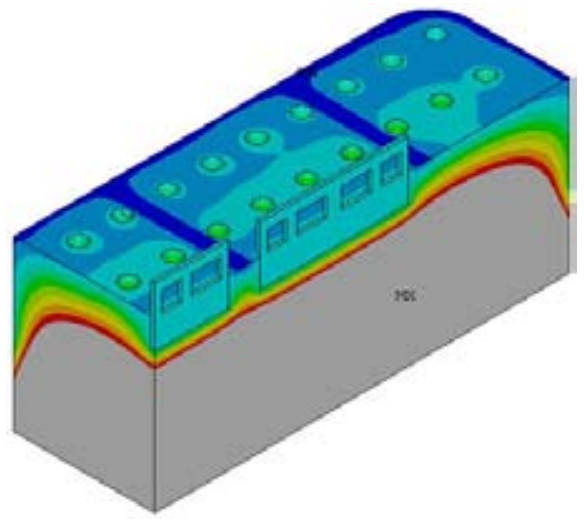

6

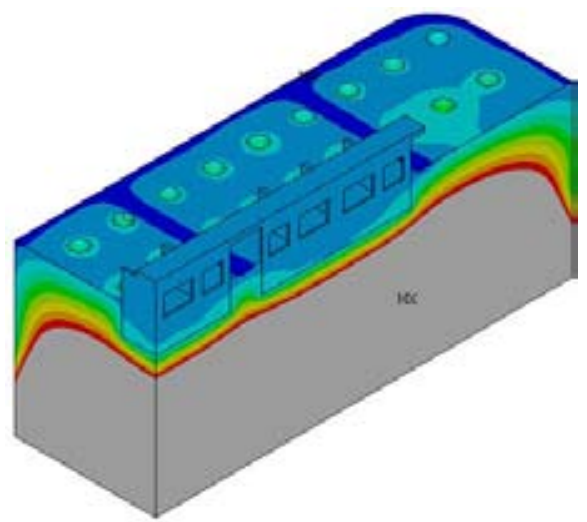

$\Gamma$

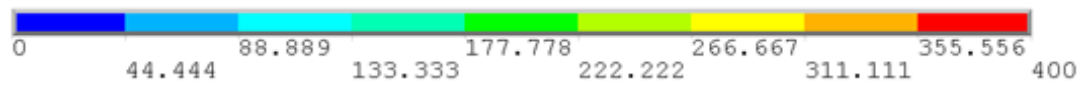

Рис. 5. Поле температур анода для всех вариантов моделирования $\left({ }^{\circ} \mathrm{C}\right):$ a - исходный вариант без ребер охлаждения; б - с продольным ребром; в - продольное ребро с поперечными ребрами; г - продольное ребро с поперечными ребрами и алюминиевым трапиком 
В табл. 1 приведены результаты расчета теплового баланса электролизера С8-БМ для всех вариантов моделирования.

На основе данных теплового баланса электролизера, представленных в табл. 1, результаты, тепловые эффекты от ребер охлаждения учтены в статье потерь тепла с поверхности анодной массы. Получив результаты моделирования, можно сделать вывод о том, что наиболее эффективной системой отвода тепла являются ребра по вариантам В и Г (26,9 и 27,0 кВт соответственно).

В табл. 2 даны результаты моделирования высоты конуса спекания и температуры анодной массы в точках замера (рис. 4).

\section{Выводы}

1. По результатам расчетов видно, что в случае установки ребер охлаждения в тело анода существенно меняется профиль конуса спекания. Происходит значимое снижение его высоты по центру анода и периферии в зависимости от конструкции ребер. Также на-

Таблица 1. Тепловой баланс электролизера С8-БМ

\begin{tabular}{|c|c|c|c|c|c|c|c|c|}
\hline \multirow{2}{*}{ Номер варианта } & \multicolumn{8}{|c|}{ C-8БМ } \\
\hline & \multicolumn{2}{|c|}{ Вариант A } & \multicolumn{2}{|c|}{ Вариант Б } & \multicolumn{2}{|c|}{ Вариант В } & \multicolumn{2}{|c|}{ Вариант Г } \\
\hline Сила тока, кА & \multicolumn{2}{|c|}{ 174кA } & \multicolumn{2}{|c|}{ 174кА } & \multicolumn{2}{|c|}{ 174кA } & \multicolumn{2}{|c|}{ 174кA } \\
\hline МПР, см & \multicolumn{2}{|c|}{4.4} & \multicolumn{2}{|c|}{4.4} & \multicolumn{2}{|c|}{4.4} & \multicolumn{2}{|c|}{4.4} \\
\hline $\begin{array}{l}\text { ПОТЕРИ ТЕПЛА С ПОВЕРХНОСТИ } \\
\text { ЭЛЕКТРОЛИЗЕРА }\end{array}$ & кВт & $\%$ & кВТ & $\%$ & кВт & $\%$ & кВт & $\%$ \\
\hline С АНОДНОГО УСТРОЙСТВА & 180.8 & 46.40 & 181.5 & 46.52 & 182.0 & 46.57 & 182.0 & 46.64 \\
\hline в том числе: & & & & & & & & \\
\hline с анодных штырей и анодной шины & 29.9 & 7.68 & 29.2 & 7.50 & 28.3 & 7.25 & 28.2 & 7.24 \\
\hline с анодной массы & 23.4 & 6.00 & 25.1 & 6.44 & 26.9 & 6.87 & 27.0 & 6.93 \\
\hline с анодного кожуха & 91.1 & 23.37 & 90.7 & 23.26 & 90.4 & 23.13 & 90.4 & 23.15 \\
\hline с поверхности засыпки & 36.4 & 9.34 & 36.4 & 9.33 & 36.4 & 9.32 & 36.4 & 9.32 \\
\hline ПРОДОЛЬНЫЕ СТЕНКИ КАТОДА & 141.1 & 36.21 & 140.9 & 36.13 & 141.1 & 36.10 & 140.7 & 36.05 \\
\hline в том числе: & & & & & & & & \\
\hline фланец продольной стенки & 19.9 & 5.10 & 19.9 & 5.09 & 19.9 & 5.09 & 19.8 & 5.08 \\
\hline верх продольной стенки & 58.6 & 15.03 & 58.4 & 14.98 & 58.5 & 14.98 & 58.3 & 14.94 \\
\hline низ продольной стенки & 25.7 & 6.59 & 25.7 & 6.58 & 25.7 & 6.57 & 25.6 & 6.57 \\
\hline блюмсы и катодная шина & 37.0 & 9.49 & 37.0 & 9.48 & 37.0 & 9.46 & 37.0 & 9.47 \\
\hline ТОРЦЕВЫЕ СТЕНКИ КАТОДА & 40.9 & 10.48 & 40.8 & 10.45 & 40.8 & 10.45 & 40.7 & 10.42 \\
\hline в том числе: & & & & & & & & \\
\hline фланец торцевой стенки & 7.1 & 1.83 & 7.1 & 1.82 & 7.1 & 1.82 & 7.1 & 1.82 \\
\hline верх торцевой стенки & 22.8 & 5.86 & 22.8 & 5.84 & 22.8 & 5.84 & 22.7 & 5.82 \\
\hline низ торцевой стенки & 10.9 & 2.79 & 10.9 & 2.79 & 10.9 & 2.79 & 10.9 & 2.78 \\
\hline ДНИЩЕ КАТОДА & 26.9 & 6.91 & 26.9 & 6.90 & 26.9 & 6.89 & 26.9 & 6.89 \\
\hline $\begin{array}{l}\text { ВСЕГО ТЕПЛА С ПОВЕРХНОСТИ } \\
\text { ЭЛЕКТРОЛИЗЕРА }\end{array}$ & 389.7 & 100.00 & 390.1 & 100.00 & 390.9 & 100.00 & 390.3 & 100.00 \\
\hline
\end{tabular}


Таблица 2. Результаты моделирования высоты конуса спекания и температуры анодной массы для ребер охлаждения различной конфигурации, установленных на поверхность анода

\begin{tabular}{|l|c|c|c|c|c|c|c|c|}
\hline $\begin{array}{c}\text { Номер } \\
\text { варианта }\end{array}$ & $\begin{array}{c}\text { Температура } \\
\text { электролита, } \\
{ }^{\circ} \mathrm{C}\end{array}$ & $\begin{array}{c}\text { Перепад } \\
\text { напряжения } \\
\text { в аноде, мВ }\end{array}$ & $\mathrm{h} 1, \mathrm{mм}$ & $\mathrm{h} 2, \mathrm{mM}$ & $\mathrm{h} 3, \mathrm{~mm}$ & $\mathrm{~T} 1,{ }^{\circ} \mathrm{C}$ & $\mathrm{T} 2,{ }^{\circ} \mathrm{C}$ & $\mathrm{T} 3,{ }^{\circ} \mathrm{C}$ \\
\hline Вариант А & 955.9 & 0.559 & 340 & 366 & 559 & 152 & 170 & 115 \\
\hline Вариант Б & 955.8 & 0.561 & 443 & 397 & 563 & 91 & 130 & 110 \\
\hline Вариант В & 955.7 & 0.563 & 495 & 451 & 581 & 91 & 130 & 110 \\
\hline Вариант Г & 955.7 & 0.563 & 495 & 459 & 581 & 79 & 126 & 110 \\
\hline
\end{tabular}

блюдается изменение профиля вдоль анода, при установке ребер профиль становится волнообразным.

2. Наибольшее снижение высоты конуса спекания и температуры по центру анода наблюдается для конструкции ребер по варианту В и Г. Данный вариант также приводит к снижению уровня КПК (параметр h3, рис. 4) по периферии на 22 мм и снижению температуры (точка Т3, рис. 4) на $5{ }^{\circ} \mathrm{C}$.

Работа выполнена в рамках сотрудниества между ФГАОУ ВПО «Сибирский федеральный университет» и ООО «РУСАЛ ИТЦ». Полученные результаты будут использованы при дальнейщей реализации работ по комплексному проекту «Разработка сверхмощной, энергоэффективной технологии получения алюминия РА-550» шифр 2015-218-06-157, выполняемой при финансовой поддержке Правительства Российской Федерации (Минобрнауки России).

\section{Список литературы}

[1] Минцис М.Я. Распределение тока в алюминиевых электролизерах. Новокузнецк.: СибГИУ, 2002. 126 c. [Mintsis М.Ya. The amperage distribution in aluminum electrolysis cells, Novokuznetsk, SibGIU, 2002, 126 p. (in Russian)]

[2] Коробов М.А., Дмитриев А.А. Самообжигающиеся аноды алюминиевых электролизеров. М.: Металлургия, 1972. 207 с. [Korobov M.A., Dmitriev A.A. Söderberg anodes of aluminum electrolyzers, Moscow, Metallurgy, 1972. 207 p. (in Russian)]

[3] Громов Б.С. Тепловые проиессы в электролизерах и миксерах алюминиевого производства. М.: Руда и металлы, 1998. 256 c. [Gromov B.S. Thermal processes in electrolytic aluminum production and mixers. Moscow, Ore and Metalls, 1998. 256 p. (in Russian)]

[4] Кулеш М.К., Фризоргер В.К., Заливной В.И., Новикхъов А.Н., Лузин И.М., Козьмин Г.Д., Агапитов В.Я., Клепчин Н.П. А.c. SU 1611991 A1 (1988) // Б.И. 1990 № 45. [Kulesh M.К., Frizorger V.K., Priming V.I., Novikhov A.N., Luzin I.M., Kozmin G.D., Agapitov V.J., Klepchin N.P. AS SU 1611991 A1 (1988) // BI 1990 number 45. (in Russian)]

[5] Дмитриев А.А., Коробов М.А., Кузнецов Е.И., Матвеев Н.С., Никитич В.Т., Романов В.П., Шулепов И.М. А.с. 278124 (1968) // Б. И. 1970. № 25. [Dmitriev A.A., Korobov M.A., Kuznetsov E.I., Matveev N.S., Nikitich V.T., Romanov V.P., Shulepov I.M. AS 278124 (1968) // BI 1970. number 25. (in Russian)] 